\title{
Similarities and differences in occurrence and temporal fluctuations in glyphosate and atrazine in small Midwestern streams (USA) during the 2013 growing season
}

Barbara J. Mahler ${ }^{a+}$, Peter C. Van Metrea, Thomas E. Burleya, Keith A. Loftin ${ }^{b}$, Michael T. Meyer $^{b}$, and Lisa H. Nowellc

aU.S. Geological Survey

1505 Ferguson Lane

Austin, Texas 78754

USA

bU.S. Geological Survey

4821 Quail Crest Blvd.

Lawrence, Kansas 66049

USA

cU.S. Geological Survey

6000 J Street, Placer Hall

Sacramento, California 95819

USA

+ Corresponding author

bjmahler@usgs.gov

pcvanmet@usgs.gov

teburley@usgs.gov

kloftin@usgs.gov

mmeyer@usgs.gov

lhnowell@usgs.gov 


\section{Temporal fluctuations in glyphosate and atrazine in small}

\section{Midwestern streams (USA) during the 2013 growing season}

Barbara J. Mahler, Peter C. Van Metre, Thomas E. Burley, Keith A. Loftin, Michael T. Meyer, and Lisa Nowell

\section{ABSTRACT}

Glyphosate and atrazine are the most intensively used herbicides in the United States. Although there is abundant spatial and temporal information on atrazine occurrence at regional scales, there are far fewer data for glyphosate, and studies that compare the two herbicides are rare. We investigated temporal patterns in glyphosate and atrazine concentrations measured weekly during the 2013 growing season in 100 small streams in the Midwestern United States.

Glyphosate was detected in $44 \%$ of samples (method reporting level $0.2 \mu \mathrm{g} / \mathrm{L}$ ); atrazine was detected above a threshold of $0.2 \mu \mathrm{g} / \mathrm{L}$ in $54 \%$ of samples. Glyphosate was detected more frequently in 12 urban streams than in 88 agricultural streams, and at concentrations similar to those in streams with high agricultural land use (>40\% row crop) in the watershed. In contrast, atrazine was detected more frequently and at higher concentrations in agricultural streams than in urban streams. The maximum concentration of glyphosate measured at most urban sites exceeded the maximum atrazine concentration, whereas at agricultural sites the reverse was true. Measurement at a 2-day interval at 8 sites in northern Missouri revealed that transport of both herbicide compounds appeared to be controlled by spring flush, that peak concentration duration was brief, but that peaks in atrazine concentrations were of longer duration than those of glyphosate. The 2-day sampling also indicated that weekly sampling is unlikely to capture peak concentrations of glyphosate and atrazine. 
Key words: ELISA; spring flush; Corn Belt; herbicide; glyphosate; atrazine 


$\begin{array}{ll}\text { Abbreviations } & \\ \text { MSQA } & \text { Midwestern Stream Quality Assessment } \\ \text { POEA } & \text { polyethoxylated amines } \\ \text { IARC } & \text { International Agency for Research on Cancer } \\ \text { EFSA } & \text { European Food Safety Authority } \\ \text { USGS } & \text { U.S. Geological Survey } \\ \text { EPA } & \text { U.S. Environmental Protection Agency } \\ \text { NRSA } & \text { National Rivers and Streams Assessment } \\ \text { ELISA } & \text { enzyme-linked immunosorbent assay } \\ \text { TxWSC } & \text { Texas Water Science Center } \\ \text { AMPA } & \text { aminomethylphosphonic acid } \\ \text { DEA } & \text { deethylatrazine } \\ \text { MRL } & \text { method reporting level } \\ \text { OGRL } & \text { Organic Geochemistry Research Laboratory } \\ \text { LC-MS/MS } & \text { liquid chromatography tandem mass spectrometry } \\ \text { NWQL } & \text { National Water Quality Laboratory } \\ \text { QC } & \text { quality control }\end{array}$




\section{Introduction}

Glyphosate and atrazine are the most heavily used herbicides in the United States, where about 135 million and 32 million $\mathrm{kg}$ of glyphosate and atrazine, respectively, were applied in 2013 for agricultural use (U.S. Geological Survey, 2015). Use of glyphosate in the United States surpassed that of atrazine in the late 1990s, concurrent with glyphosate coming off patent and the introduction of genetically modified glyphosate-resistant crops. From 2000 to 2013 , glyphosate use in the United States increased about $170 \%$ (Benbrook, 2016) while atrazine use remained relatively steady (U.S. Geological Survey, 2015).

Although glyphosate and atrazine both are herbicides, differences in chemical properties, modes of action, and use patterns can affect the magnitude and timing of concentrations in streams. Glyphosate ( $N$-[phosphonomethyl] glycine) is a weak organic acid with amine, carboxylate, and phosphate groups, and atrazine is a triazine, a class of nitrogencontaining heterocycles. Glyphosate is substantially more soluble in water than is atrazine (solubilities of $10,000-15,700 \mathrm{mg} / \mathrm{L}$ at $25^{\circ} \mathrm{C}$ and $35 \mathrm{mg} / \mathrm{L}$ at $22^{\circ} \mathrm{C}$ for glyphosate and atrazine, respectively [Agency for Toxic Substances and Disease Registry, 2003; Mackay et al., 1997]), but binds more strongly to soil ( $\mathrm{K}_{\mathrm{d}}$ values of 5-900 mL/g [Capri and Vicari, 2010]) for glyphosate and 0.7-52.1 mL/g for atrazine [Ahmad and Rahman, 2009]). Half-lives in water are shorter for glyphosate than atrazine (1.7-142 days for glyphosate [Giesy et al., 2000], 6 months for atrazine [Agency for Toxic Substances and Disease Registry, 2003]). In aerobic soil metabolism tests, the half-life for degradation of glyphosate to aminomethylphosphonic acid (AMPA) was about 2 to 5 days (U.S. Environmental Protection Agency, 2008), compared to a half-life of about 140-150 days for atrazine (ranging from 13-1800 days, as reported in the open 
literature), producing deethylatrazine (DEA) and other degradates (Farrugia et al., 2016).

Glyphosate uptake is through leaves (Giesy et al., 2000); application is foliar, and a surfactant, such as polyethoxylated amines (POEA) (Tush et al., 2013), typically is added to enhance penetration of the leaf cuticle. Glyphosate is classified as a post-emergent herbicide, but increasingly is used pre-emergence in no-till settings (Benbrook, 2016). Atrazine uptake is primarily through the roots (Gibson, 2001; Agency for Toxic Substances and Disease Registry, 2003; Curran and Lingenfelter, 2009) and is a pre-emergent herbicide. Both herbicides are used extensively for agriculture-glyphosate on a range of crops (e.g., corn, soybeans, wheat, and cotton) and atrazine primarily on corn (U.S. Geological Survey, 2015). Glyphosate also is the second most heavily used pesticide in U.S. non-agricultural settings (home/garden and industry/commercial/government) after 2,4-D (2007 estimates) (Grube et al., 2011); an estimated 12 million kg were used in non-agricultural settings in 2013 (Benbrook, 2016). Although atrazine is an ingredient in some "weed and feed" products for sale to homeowners, it is not among the top 10 pesticides used in non-agricultural settings (Grube et al., 2011). In 2015 glyphosate was classified by the International Agency for Research on Cancer (IARC) as a probable human carcinogen (Group 2A) (International Agency for Research on Cancer, 2015), but shortly afterward the European Food Safety Authority (EFSA) concluded that "the evidence does not support classification with regard to its carcinogenic potential" (European Food Safety Authority, 2015). A primary reason for this was that the IARC considered glyphosate formulations, which include adjuvants, whereas the EFSA considered the active ingredient (pure glyphosate) only (European Food Safety Authority, 2015). The IARC has found sufficient evidence in experimental animals for the carcinogenicity of atrazine, but inadequate 
evidence in humans for classification as a carcinogen (International Agency for Research on Cancer, 1999).

Glyphosate and atrazine both occur frequently in U.S. streams at low concentrations. Glyphosate is not commonly included in broad-scale pesticide monitoring programs (Battaglin et al., 2005). However, in an aggregation of 2001-10 data from 358 U.S. streams (a range of land uses), glyphosate was detected in $52 \%$ of 1,508 stream-water samples, with a median concentration of $0.03 \mu \mathrm{g} / \mathrm{L}$ (Battaglin et al., 2014). In the same data aggregation (Battaglin et al., 2014), glyphosate was reported to occur much less frequently in groundwater than in surface water; it was detected in only $5.8 \%$ of 1,171 groundwater samples collected from 807 U.S. groundwater sites. Although detailed temporal patterns in glyphosate concentrations in streams have not been described, Battaglin et al. (2005) reported similar concentrations in samples collected pre-emergence (May or June) and post-emergence (June or July) from Midwestern streams. In contrast, atrazine occurrence in surface water has been extensively studied, especially in the Midwest (e.g., Thurman et al., 1992; Battaglin et al., 2000; Kalkhoff et al., 2003; Scribner et al., 2005). Atrazine was detected in about $85 \%$ of samples collected during 1992-2001 from agricultural streams across the United States (Gilliom et al., 2006), and in 98\% of post-application samples collected during the 1990s from Midwestern streams (Scribner et al., 2005). Spring flush-a seasonal pulse of herbicide as a result of precipitation that follows pre-planting herbicide application (Stoeckel et al., 2012)-is a dominant mechanism for transporting atrazine from cropland to surface water, resulting in transitory elevated concentrations (Thurman et al., 1991; Gilliom et al., 2006). 
Here, spatial and temporal patterns in concentrations of glyphosate in Midwestern U.S. streams during the 2013 growing season (May-July) are compared with those of the more widely studied atrazine. Concentrations were measured in samples collected weekly from 100 small streams and in samples collected every 2 days from a subset of 8 streams. We evaluate the factors that affect glyphosate and atrazine occurrence and transport and examine the effect of sampling interval on identification of peak concentrations.

\section{Methods}

\subsection{Site Selection and Study Design}

As part of the U.S. Geological Survey (USGS) Midwest Stream Quality Assessment (MSQA), in collaboration with the U.S. Environmental Protection Agency (EPA) National Rivers and Streams Assessment (NRSA), 100 sites on wadeable streams (less than about $1 \mathrm{~m}$ deep in most of the sampling reach at base flow) across the U.S. Midwestern Corn Belt were selected for sample collection (Supporting Information [SI] Fig. S-1). Fifty sites were selected by the EPA using the NRSA probabilistic design (random sites) (Olsen et al., 1999); the remaining sites (targeted sites) were chosen to represent urban land use (12 sites) or to fill out a gradient in agricultural land use (38 targeted sites plus the 50 random sites). Watershed characteristics and methods for watershed delineation and sources of land use and other spatial variables are described in SI (Section I; Tables S-1 to S-3). The study area covers 600,000 km². MSQA watershed areas ranged from 3.5 to $2,900 \mathrm{~km}^{2}$, except for one site with a watershed area of $6,350 \mathrm{~km}^{2}$; median area was $170 \mathrm{~km}^{2}$. Mean land use for the MSQA watersheds is $54 \%$ row crop, $11 \%$ pasture and hay, and $8 \%$ urban (compared to 57,12 , and $10 \%$, respectively, for the 
whole region), and most of the remainder is woodlands and grasslands (SI Fig. S-1). The 88 agricultural-gradient sites ("agricultural sites") were classified as low-intensity agriculture (lowag; $\leq 20 \%$ row crop; $n=11$ ), medium-intensity agriculture (med-ag; $>20$ to $\leq 40 \%$ row crop; $n=14$ ), or high-intensity agriculture (high-ag; >40\% row crop; $n=63$ ). The 12 urban-indicator sites ("urban sites") ranged from 18 to $88 \%$ urban land use.

At each of the 100 MSQA sites, 12 samples were collected weekly during May 6-August 9, 2013 ("weekly samples"), except for two 2-week periods (May 27-June 6 and July 1-10) during each of which only one sample was collected. In addition, a subset of eight sites in Missouri was selected for more temporally intensive sample collection ("2-day sites") (SI Fig. S1); at these sites samples were collected every 2 days from May 15 to July 23 (or to July 11 at one site) ("2-day samples") in addition to the weekly samples.

\subsection{Sample Collection and Analytical Methods}

Weekly samples were collected according to standard USGS protocols, typically by using a depth-integrating sampler at multiple locations across the stream cross section (U.S.

Geological Survey, 2006). The composited sample was placed into a Teflon churn, and a 20-mL aliquot was removed through a large-bore needle into a plastic syringe and filtered through a 0.7- $\mu \mathrm{m}$ pore-size glass fiber disk filter into a $40-\mathrm{mL}$ amber glass vial. The 2 -day samples were collected as grab samples at the approximate mid-section of the stream and filtered in the same way as the weekly samples. Vials were stored chilled and shipped on ice to the appropriate laboratory within 48 hours of collection, or frozen for as long as 3 days before shipping. 
Details of analytical methods are provided in SI. In brief, glyphosate concentrations in weekly and 2-day samples and atrazine concentrations in 2-day samples were measured by enzyme-linked immunosorbent assay (ELISA) at the USGS Texas Water Science Center (TxWSC) laboratory (Austin, TX). The glyphosate degradate AMPA and the atrazine degradate DEA are not measured by this method. The method reporting levels (MRL) were 0.2 and $0.1 \mu \mathrm{g} / \mathrm{L}$ for glyphosate and atrazine, respectively. Selected weekly samples collected at 27 sites (160 samples) also were analyzed for glyphosate at the USGS Organic Geochemistry Research Laboratory (OGRL) (Lawrence, KS) by liquid chromatrography tandem mass spectrometry LCMS/MS (Meyer et al., 2009) as a check on the ELISA analyses (AMPA also was measured) (SI sections II and III). The MRLs for glyphosate and AMPA by LC-MS/MS were both $0.02 \mu \mathrm{g} / \mathrm{L}$. Atrazine and DEA concentrations in weekly samples were analyzed at the USGS National Water Quality Laboratory (NWQL) by LC-MS/MS (Sandstrom et al., 2015). The MRLs were $0.005 \mu \mathrm{g} / \mathrm{L}$ for atrazine and 0.011 for DEA, but reporting levels were raised in several samples because of interferences, low-level blank contamination, or changes in instrument sensitivity, as noted by the NWQL. Some concentrations were flagged as estimated ("E") on the basis of one or more qualifiers (Childress et al., 1999). Weekly samples collected at the eight 2-day sites and analyzed by LC-MS/MS also were analyzed for atrazine at the TxWSC by ELISA for comparison of the two methods.

\subsection{Statistical Analysis}

Statistical analyses were done using Statistica v. 12 (Dell, Inc., Tulsa, OK). Differences between populations were evaluated with the nonparametric Mann-Whitney $U$ test. Multiple 
comparisons were done with a post hoc comparison of mean ranks of all pairs of groups with a Bonferroni adjustment. Correlations and trends were evaluated with the nonparametric Kendall's tau correlation coefficient. Results were accepted as significant for $p \leq 0.05$.

\subsection{Quality Control}

Quality control (QC) consisted of laboratory blanks, spikes, and duplicates; field blanks, spikes, and duplicates; and comparison of results of analysis of the same sample by ELISA at the TxWSC and by LC-MS/MS at the OGRL (glyphosate) or the NWQL (atrazine). Detailed QC results are provided in SI.

\section{Results}

\subsection{Glyphosate and Atrazine Use and Occurrence in Agricultural and Urban Corn Belt Streams}

Patterns in agricultural use of glyphosate and atrazine in the MSQA study area (SI Table S-4) mirror those nationally. Estimated agricultural uses of glyphosate in the study area have increased about 50-fold since 1992, and in 2013 were about 3 times those of atrazine (SI Fig. S2). Median 2013 use intensity across the watersheds studied was 72 and $20 \mathrm{~kg} / \mathrm{km}^{2}$ for glyphosate and atrazine, respectively, but measured concentrations of glyphosate overall were slightly lower than those of atrazine. Maximum concentrations measured in weekly samples at a site ranged from nondetection $(<0.2 \mu \mathrm{g} / \mathrm{L}$ ) to $27.8 \mu \mathrm{g} / \mathrm{L}$ (median of $1.68 \mu \mathrm{g} / \mathrm{L}$ ) for glyphosate and from 0.04 to $120 \mu \mathrm{g} / \mathrm{L}$ (median of $2.37 \mu \mathrm{g} / \mathrm{L}$ ) for atrazine (Fig. 1; SI Table S-5).

Glyphosate and atrazine detection frequencies and concentrations differed by land use

(Fig. 2a; complete data provided in SI Table S-5). Glyphosate, detected at a concentration above the MRL of $0.2 \mu \mathrm{g} / \mathrm{L}$ in $44 \%$ of all weekly samples $(n=1,186)$, was most frequently detected in 
urban streams ( $63 \%$ of urban stream samples, $n=144)$. Atrazine was detected above its MRL of $0.005 \mu \mathrm{g} / \mathrm{L}$ in $92 \%$ of samples. However, when evaluated at the same $0.2 \mu \mathrm{g} / \mathrm{L}$ threshold as glyphosate, atrazine was detected in $54 \%$ of weekly samples, and most frequently in med-ag streams $(75 \%, n=177)$. The distributions of detection frequencies for random and targeted agricultural sites were similar for both glyphosate and atrazine (Fig. 2b), indicating that the targeted site-selection approach did not produce biased results for these pesticides in agricultural streams. Results for MSQA agricultural sites thus can be used to infer concentration ranges of glyphosate and atrazine in unsampled wadeable streams in agricultural settings across the region. Different distributions of detections for the urban sites, however, indicate that investigation of this high-impact, small-footprint land use requires a targeted selection approach.

The maximum atrazine concentration measured at most of the agricultural sites exceeded the maximum glyphosate concentration measured (high-ag, 66\% of sites; med-ag, $79 \%$ of sites; low-ag, $100 \%$ of sites). The difference in concentrations was greatest for the medag sites, where the median maximum atrazine concentration measured at a site was $5.17 \mu \mathrm{g} / \mathrm{L}$, which is about 4.7 times higher than the median maximum glyphosate concentration (1.09 $\mu \mathrm{g} / \mathrm{L})$. At the urban sites the reverse was true: at every site, the maximum glyphosate concentration measured exceeded the maximum atrazine concentration measured, and the median maximum glyphosate concentration $(2.13 \mu \mathrm{g} / \mathrm{L})$ was 4.25 times higher than the median maximum atrazine concentration $(0.50 \mu \mathrm{g} / \mathrm{L})$. For agricultural streams, maximum glyphosate concentrations were highest for high-ag sites and lowest for low-ag sites (median values of 2.23, 1.09, and $0.34 \mu \mathrm{g} / \mathrm{L}$ at high-, med-, and low-ag sites, respectively), and maximum 
concentrations at urban stream sites (median of $2.13 \mu \mathrm{g} / \mathrm{L}$ ) were similar to those at high-ag sites. Maximum atrazine concentrations at high- and med-, and low-ag stream sites had medians of $2.66,5.17$, and $1.16 \mu \mathrm{g} / \mathrm{L}$, respectively, exceeding the median maximum concentration of $0.50 \mu \mathrm{g} / \mathrm{L}$ measured at urban stream sites.

\subsection{Factors Affecting Fate and Transport}

Nonparametric correlations were computed between the maximum weekly concentration measured at each site and spatial variables (SI Table S-1) that might affect herbicide occurrence and transport in a watershed: geographic variables (watershed area [BasinGIS_km2]; riparian area [Riparian20m_km2]; riparian percentage of watershed [RiparianPct_20m]; impervious cover in riparian area [r20_Imperviousness2011]); management variables (agricultural glyphosate and atrazine use in 2103 [GLYPHOSATE2013 and ATRAZINE2013, respectively], tile drains [TileDrnsCens2012]); land-use variables (cultivated cropland in 2011 [CultivatedCrops2011]; area planted in corn in 2013 [CornCDL2013]; area planted in soybeans in 2013 [SoybeansCDL2013]; urbanized land in 2011 [UrbanTotal2011]; population density in 2010 [PopDensity2010]); soil properties (soil erodibility [KfactorUpperHorizon]; organic-matter content [OrganicMatter]; sand content [SandContent]; permeability [Permeability]; soil restrictive layer at 25-cm depth [SRL25Agland]; shale type [ShaleTotal_STG]), and hydrologic variables (base-flow index [BaseFLowlndex]; average annual runoff for 2012 [Runoff2012]; total precipitation during the study [Precipitation_May6ToAug9_2013]). (Additional information on explanatory variables is provided in SI Table S-1.) There were fewer significant correlations of explanatory variables with 
maximum glyphosate concentrations than with maximum atrazine concentrations (Table 1;

complete results provided in SI Table S-6).

Table 1. Non-parametric Kendall's tau correlation coefficient values used to assess the correlation between

maximum glyphosate (GLY_Max) and atrazine (ATR_Max) concentrations measured in weekly samples at a site and potential explanatory variables. Kendall's tau values significant at $\mathrm{p}<0.05$ shown in bold italics.

All other variable definitions and sources given in SI table S-1 (data dictionary).

\begin{tabular}{lrrrrr} 
& \multicolumn{2}{c}{ All sites } & \multicolumn{2}{c}{ Agricultural sites only } \\
Explanatory variable & GLY_Max & ATR_MAX & GLY_Max & ATR_MAX \\
GLY_Max & 1.00 & $\mathbf{0 . 3 0}$ & 1.00 & $\mathbf{0 . 3 5}$ \\
ATR_MAX & $\mathbf{0 . 3 0}$ & 1.00 & $\mathbf{0 . 3 5}$ & 1.00 \\
GLYPHOSATE2013 & $\mathbf{0 . 2 1}$ & $\mathbf{0 . 2 1}$ & $\mathbf{0 . 2 4}$ & 0.10 \\
ATRAZINE2013 & $\mathbf{0 . 1 9}$ & $\mathbf{0 . 3 1}$ & $\mathbf{0 . 2 2}$ & $\mathbf{0 . 2 2}$ \\
BasinGIS_km2 & $\mathbf{0 . 1 4}$ & 0.12 & 0.13 & 0.07 \\
r20_Imperviousness2011 & $\mathbf{0 . 1 7}$ & -0.04 & $\mathbf{0 . 1 8}$ & 0.13 \\
Riparian20m_km2 & 0.10 & $\mathbf{0 . 1 7}$ & 0.10 & 0.11 \\
RiparianPct_20m & -0.09 & $\mathbf{0 . 2 6}$ & -0.06 & $\mathbf{0 . 2 3}$ \\
CultivatedCrops2011 & $\mathbf{0 . 2 0}$ & 0.12 & $\mathbf{0 . 2 6}$ & -0.01 \\
UrbanTotal2011 & 0.12 & -0.07 & 0.11 & 0.09 \\
PopDensity2010 & 0.08 & -0.10 & 0.06 & 0.05 \\
KfactorUpperHorizon & 0.05 & $\mathbf{0 . 2 1}$ & 0.04 & $\mathbf{0 . 2 9}$ \\
OrganicMatter & 0.12 & $-\mathbf{0 . 2 0}$ & 0.13 & $\mathbf{- 0 . 1 9}$ \\
SandContent & -0.01 & $\mathbf{- 0 . 1 4}$ & 0.00 & $\mathbf{- 0 . 2 5}$ \\
Permeability & -0.09 & $\mathbf{- 0 . 2 2}$ & -0.11 & $\mathbf{- 0 . 3 1}$ \\
SRL25Agland & 0.04 & $\mathbf{0 . 2 5}$ & 0.06 & $\mathbf{0 . 2 4}$ \\
BaseFlowIndex & -0.02 & $\mathbf{- 0 . 3 1}$ & -0.06 & $\mathbf{- 0 . 3 7}$ \\
Runoff2012 & -0.04 & 0.02 & -0.04 & 0.09 \\
ShaleTotal_STG & 0.04 & $\mathbf{0 . 1 5}$ & 0.07 & 0.11 \\
TileDrnsCens2012 & 0.12 & 0.00 & 0.13 & 0.02 \\
CornCDL2013 & $\mathbf{0 . 1 7}$ & 0.09 & $\mathbf{0 . 2 2}$ & -0.05 \\
SoybeansCDL2013 & $\mathbf{0 . 2 3}$ & $\mathbf{0 . 2 2}$ & $\mathbf{0 . 2 9}$ & 0.10 \\
Precipitation_May6ToAug9_2013 & 0.03 & 0.05 & 0.07 & 0.06
\end{tabular}

\subsection{Parent and Degradate Compounds}

Concentrations of glyphosate, AMPA, atrazine, and DEA were compared for the 27 sites where all four compounds were measured (15 agricultural sites [13 high-ag and 2 low-ag] and 12 urban sites; 160 samples). The ratio of AMPA to glyphosate (AMPA:Gly) exceeded the ratio 
of DEA to atrazine (DEA:Atr) in 90\% (106 of 118) of the samples in which all four compounds were detected; the median AMPA:Gly (2.3) was about 6 times greater than the median DEA:Atr (0.39), indicating much greater transformation of glyphosate to AMPA than atrazine to DEA during transport. There was a significant trend in AMPA:Gly concentrations through the growing season at only 4 of the 27 sites: 3 upward trends and 1 downward trend. In contrast, there were significant trends in DEA:Atr at 8 of the 27 sites, all upward. These results are consistent with those reported by Battaglin et al. (2005) for Corn Belt streams in 2002: no significant difference in AMPA:Gly was observed between pre-emergence, post-emergence, and post-harvest samples, but an increase in DEA:Atr was observed across these three periods. Battaglin et al. (2005) attributed the difference to transport of glyphosate primarily in surface runoff throughout the three periods and transport of atrazine in surface runoff early in the season transitioning to transport in groundwater (with larger DEA:Atr ratios) later in the season.

Glyphosate exhibited more degradation at agricultural sites than urban sites, but the opposite was true for atrazine. The median AMPA:Gly for samples from the agricultural sites (3.31) was significantly higher (indicating more degradation) than the median for the urban sites (1.47) (SI Fig. S-3), and similarly the minimum AMPA:Gly, which indicates the least amount of degradation, measured at a site was significantly higher at the agricultural sites (median of the minumums at each site of 1.78) than at the urban sites (median of 0.79 ). In contrast, the median DEA:atrazine was lower at agricultural sites than urban sites (medians of 0.32 and 0.60 , respectively) (SI Fig. S-3), as was the minimum DEA:atrazine ratio (median of 0.17 at agricultural sites and 0.27 at urban sites). 


\subsection{Timing of peak concentrations}

Glyphosate maxima at individual sites occurred throughout the study period, whereas atrazine maxima usually occurred between mid-May and the beginning of July (Figs. 3a,b). The highest measured glyphosate concentrations across the Corn Belt region (quantified here as the $75^{\text {th }}$ percentile of the maxima measured in weekly samples for each sampling week) mostly occurred in late June and early July for agricultural and urban streams; there was a second peak in glyphosate concentration in late July in urban streams (Fig. 3c). The highest concentrations of atrazine preceded those of glyphosate by about a month (Fig. 3d). Peak glyphosate concentrations were similar across land uses, whereas peak concentrations of atrazine were substantially higher at agricultural sites than urban sites (Figs. 3c,d).

\subsection{Two-day Sampling Frequency}

In contrast to the weekly samples, concentrations of glyphosate and atrazine in 2-day samples had a pronounced maximum in late May at six and seven of the eight 2-day sites, respectively; time-series patterns for the two herbicides at most sites were similar (Fig. 4; SI Fig. S4; SI Table S-7). Peak concentrations at most sites co-occurred with or occurred just after substantial precipitation ( 39 to $74 \mathrm{~mm}$ ) on May 21 and 22 following a period of about 9 days of very little or no precipitation (SI Fig. S-4). The maximum concentration measured in a 2-day sample exceeded that measured in the corresponding weekly sample at seven (glyphosate) and six (atrazine) of the 2-day sites, and at most sites the difference between the 2-day and weekly samples was greater for glyphosate than for atrazine. 


\section{Discussion}

\subsection{Herbicide-use intensity, and timing and occurrence in Corn Belt streams}

Glyphosate was detected more frequently in urban streams sampled than agricultural streams, and concentrations in the two settings were similar, whereas atrazine was detected more frequently and at higher concentrations in agricultural streams than in urban streams. The results are consistent with the differing use patterns of the two herbicides: glyphosate is the second most heavily used pesticide in non-agricultural settings (2007 estimates), but atrazine does not figure among the top 10 (Grube et al., 2011).

Despite about a 2.5 -fold increase in glyphosate use in the study area since 2002 , the detection frequency for glyphosate in agricultural settings measured in this study (21-43\% for the three agricultural-stream categories, Fig. $2 a$ ) is similar to a frequency of $35-40 \%$ reported by Battaglin et al. (2005) for 51 Midwestern streams sampled in in 2002 during May-July. However, the MRL for this study $(0.2 \mu \mathrm{g} / \mathrm{L})$ was twice the MRL of $0.1 \mu \mathrm{g} / \mathrm{L}$ used by Battaglin et al. The effect of MRL on detection frequency for this study can be estimated on the basis of the 160 samples analyzed for glyphosate by LC-MS/MS using a lower MRL (0.02 $\mu \mathrm{g} / \mathrm{L})$. For these samples, the glyphosate detection frequency above a threshold of $0.1 \mu \mathrm{g} / \mathrm{L}$ was $63 \%$, about $50 \%$ higher than the detection frequency of $40 \%$ when a threshold of $0.2 \mu \mathrm{g} / \mathrm{L}$ was used. (The detection frequency above a threshold of $0.02 \mu \mathrm{g} / \mathrm{L}$ was $87 \%$, illustrating the importance of $M R L$ on determining detection frequency). Assuming that the distribution of concentrations is the same in the 160-sample subset as in the full MSQA dataset (distributions above a threshold of $0.2 \mu \mathrm{g} / \mathrm{L}$ are virtually identical), this indicates that glyphosate detection frequencies for all samples in the MSQA study might have been about 50\% higher (i.e., 32-64\% for the three 
agricultural-stream categories) had the MRL been the same as that used for the 2002 samples $(0.1 \mu \mathrm{g} / \mathrm{L})$ reported by Battaglin et al. (2005)

Although the prevalence of concentrations less than the MRL in both data sets hampers quantitative comparison of differences in concentrations, higher AMPA:gly ratios in 2013 than in 2002 indicate that total glyphosate concentrations (glyphosate+AMPA) in 2013 also likely are higher than in 2002 and more commensurate with the increase in glyphosate use than are concentrations of glyphosate alone. The median AMPA:Gly measured at agricultural sites (3.31) during the MSQA (May-August 2013) was substantially larger than those reported for midwestern streams sampled in 2002 (median AMPA:Gly of 0.85, 1.29, and 1.87 for preemergence (May-June), post-emergence (July-August), and post-harvest (Sept-Nov) sample times, respectively) (Battaglin et al., 2005). The greater prevalence of the degradation product in 2013 relative to results from 2002 reported by Battaglin et al. (2005) is of particular note given that none of the samples for this study were collected post-harvest (SeptemberNovember). Higher AMPA:Gly ratios in 2013 relative to 2002 might reflect accumulation of AMPA in soils over a decade during which glyphosate use increased by a factor of about 2.5, given that AMPA degrades more slowly and binds more strongly to soil than does glyphosate (Giesy et al., 2000).

Despite relatively steady use of atrazine in the region between 2002 and 2013 (SI Fig. S2 ), the detection frequency for atrazine measured in agricultural settings for this study (71\% for agricultural sites combined) was less than that measured by Battaglin et al. (2005) (medians of 94 and $96 \%$ for pre-emergence and post-emergence samples, respectively) when evaluated at the same MRL $(0.1 \mu \mathrm{g} / \mathrm{L})$. Although this comparison must be interpreted with caution, as 
different stream sites were sampled for the two studies, the results are consistent with those of previous studies that have reported a decrease in atrazine concentration in the Midwest over the last several decades despite relatively steady use (Scribner et al., 2000; Sullivan et al., 2009; Ryberg et al., 2010) and coincident with numerous risk-reduction measures such as setbacks and reduced application rates (Ryberg et al., 2010).

The relatively high detection frequency of glyphosate in urban streams measured in this study is substantially greater than that reported for U.S. urban streams sampled in 2002, even though the estimated increase in use in non-agricultural applications from 2002 to 2013 was just 25\% (Benbrook, 2016). Kolpin et al. (2006) detected glyphosate in $17.5 \%$ of samples collected between July and November 2002 from 10 urban streams ( 29 stream samples and 11 samples of treated effluent) at an MRL of $0.1 \mu \mathrm{g} / \mathrm{L}$, whereas glyphosate was detected in $63 \%$ of urban stream samples collected for this study at an MRL of $0.2 \mu \mathrm{g} / \mathrm{L}$. Some of this difference, however, might be attributable to Kolpin et al.'s collection of samples from across the United States and during late summer and autumn. Other studies have noted the frequent occurrence of glyphosate in urban settings (e.g., Botta et al., 2009; Hanke et al., 2010; Glozier et al., 2012; Ramwell et al., 2014). The vulnerability of urban streams to glyphosate contamination might be related to urban watersheds having a greater percentage of impervious surfaces than agricultural watersheds, which facilitates transport of freshly applied herbicide, particularly when applied on or near hard surfaces such as driveways, sidewalks, and roads (Hanke et al., 2010; Ramwell et al., 2014). Additionally, connectivity of the landscape to waterways is provided in urban areas by curb-and-gutter drainage and storm drains, which are designed to rapidly route runoff to a nearby stream (Moran and TenBrook, 2011). 
Differences in timing of peak glyphosate and atrazine concentrations reflect the timing of application, which in turn reflects mode of action. Because glyphosate uptake is foliar, glyphosate is primarily used as a post-emergent herbicide, but it also can be used to kill weeds pre-emergence, whereas atrazine uptake is through roots and is primarily used pre-emergence. As a result, peak concentrations in weekly samples of glyphosate in watersheds across the Corn Belt occurred throughout the study period, whereas peak concentrations of atrazine primarily occurred during the first part of the study period (Figs. 3a,b). The highest concentrations of glyphosate occurred in late June and early July, about a month later than those of atrazine (Fig. 3), consistent with post-emergence application of glyphosate (SI Fig. S-5) and pre-emergence application of atrazine.

Timing of application and therefore peak concentrations of the two herbicides during the study likely occurred later than is typical because cool, wet weather in spring 2013 delayed corn planting: By May $12,2013,28 \%$ of the nation's corn crop had been planted compared to $85 \%$ on the same day in 2012 (Eligon, 2013). In the five Corn Belt states that make up most of the MSQA study area (IA, IL, IN, OH, MO), most of the 2013 crop was planted during May 12-19 (SI Fig. S-6; SI Table S-8). For example, the percentage of the 2013 corn crop planted in lowa increased from 17 to $74 \%$ during that week. A later peak in glyphosate concentrations in urban streams in late July coincided with precipitation around July $20^{\text {th }}$ that was preceded by a week of dry weather. This warm dry weather might have prompted weed growth and use of glyphosate on urban landscapes, followed by transport to streams by runoff resulting from the subsequent precipitation. 
Might concentrations of glyphosate and atrazine have peaked prior to the first samples collected for the MSQA? On the basis of longer temporal records collected by the USGS for atrazine at other streams in the Corn Belt, we conjecture that the period of the study successfully captured much of the spring flush of atrazine at a majority of the MSQA sites. In 23 streams and rivers in the Corn Belt where the USGS collects samples for analysis of atrazine every 2 weeks (most of which have watersheds larger than the MSQA streams and 3 of which were included in the MSQA sampling), the peak measured concentration of atrazine for 2013 in all cases occurred after May 8, 2013 (the onset of MSQA sampling) (U.S. Geological Survey, 2016) (SI Fig. S-7). Further, by May 8 less than $10 \%$ of the corn crop had been planted in four of the five principal MSQA states (the exception is Missouri, in which $28 \%$ of the crop had been planted) (SI Fig. S-6; SI Table S-8); atrazine is dominantly used on corn. Because atrazine is a pre-emergent herbicide and glyphosate is pre- and post-emergent, we hypothesize that if much of the spring flush of atrazine was captured during the MSQA study, then it was captured for glyphosate as well.

\subsection{Effects of chemical properties and watershed characteristics on transport and occurrence}

Glyphosate appears to be less efficiently transported than atrazine from the site of application to streams, as reflected by maximum glyphosate concentrations that are lower than those of atrazine despite higher use. Maximum glyphosate concentration at a site (as measured in weekly samples) was correlated with only two potential transport variables, watershed area (BasinGIS_km2) and the percentage of area within $20 \mathrm{~m}$ of a stream that is impervious cover (ImperviousCoverRiparian), and the correlations were weak (Kendall's tau < 0.20) (Table 1). 
Maximum atrazine concentration at a site also was weakly correlated with impervious cover in riparian areas, but, in contrast to glyphosate, had stronger correlations (Kendall's tau >0.20) with other variables likely to affect transport: organic matter and permeability (negative correlation), and soil $\mathrm{K}$ factor and soil restrictive layer (SRL25Agland) (positive correlation). These correlations are consistent with higher maximum atrazine concentrations measured at med-ag sites relative to other site types: the median soil restrictive layer for med-ag sites, most of which are in northern Missouri, was about 30\%, whereas medians for high- and low-ag sites were less than 3\% (SI Table S-2). However, the strongest correlation between maximum atrazine concentration at a site and an independent variable was with base-flow index (Kendall's tau of -0.31), a measure of surface water dilution by groundwater, and the relation with this variable was even stronger (Kendall's tau of -0.37) if only agricultural sites were considered. The absence of correlations with soil characteristics and base-flow index for glyphosate might reflect the strong affinity of glyphosate to bind to soils, effectively eliminating subsurface transport. In contrast, these same variables likely affect the degree to which atrazine is transported to streams.

The absence of correlations with soil characteristics and base-flow index for glyphosate might also reflect its rapid degradation in water and soil. In the MSQA, glyphosate underwent a greater degree of transformation than atrazine, as reflected by a median AMPA:Gly (2.3) that was substantially larger than the median DEA:Atrazine (0.39) (SI Fig. S-3), although this comparison does not consider that atrazine has other degradates in addition to DEA. Additionally, degradation of these herbicides varied by land use, with greater transport of parent glyphosate to the receiving stream in urban areas than in agricultural areas; the 
opposite was true for atrazine. Impervious surfaces and greater connectivity between the urban landscape and receiving water bodies (general characteristics of urban watersheds) might facilitate the efficient transport of glyphosate in urban areas, as would smaller watershed size (a characteristic of urban watersheds in this study).

\subsection{Sampling frequency affects apparent timing of peak concentrations}

The 2-day sampling reveals early (May 20-22) peak concentrations of both

glyphosate and atrazine consistent with a spring-flush mechanism. Although such a mechanism has been demonstrated on a regional scale for atrazine (Thurman et al., 1991; Gilliom et al., 2006), this study indicates that glyphosate maxima measured were similarly controlled at the eight Missouri sites investigated. Coincident peaks in the two herbicides at most of the 2-day sites indicate similar timing of application, the strong influence of precipitation, and (or) a similar transport mechanism. These early peaks in glyphosate and atrazine concentrations at most of the 2-day sites were not observed in the weekly samples from the same sites (Fig. 4, SI Fig. S-4). The tendency of the weekly samples to miss peak concentrations was exacerbated when the weekly sampling was extended to a 2-week interval such as during late May/early June. At a few sites peak concentration was captured serendipitously by a weekly sample collected on a different day than the 2-day sample (e.g., glyphosate at MO_Perche and atrazine at MO_Goodwater [SI Fig S-4]), further demonstrating the transitory nature of glyphosate and atrazine pulses.

Glyphosate and atrazine maxima measured in the 2-day samples at 6 of the 8 sites co-occurred with or occurred just after substantial precipitation (39 to $74 \mathrm{~mm}$ ) on May 21 and 22 following a period of about 9 days of very little or no precipitation (e.g., Fig. 4; SI Fig. S-4). 
The 9 days of dry weather, which were preceded by about week of precipitation totaling 36 to $62 \mathrm{~mm}$, likely were a window for planting and for herbicide application: the amount of corn planted in Missouri increased from $18 \%$ on May 12 to $70 \%$ on May 19 (SI table S-8). Following the initial spring flush of glyphosate and atrazine, however, concentrations measured in the 2day and weekly samples at a site were similar in their magnitudes and temporal patterns, indicating that a weekly sampling interval might be sufficient to characterize glyphosate and atrazine concentrations at these sites outside of spring flush, and providing potential guidance for future monitoring.

Although peak concentrations of glyphosate and atrazine coincided at most of the eight 2-day sites, peak concentrations of glyphosate typically decreased to near background concentrations by the time the next 2-day sample was collected, whereas atrazine peaks tended to be broader (e.g., MO_Fish, MO_Skull, SI Fig. S-4). This might reflect the higher capacity of glyphosate to bind to soil, limiting its transport to overland flow, whereas atrazine can also be transported by interflow or through tile drains, extending its transport time (Duffner et al., 2012). Glyphosate also degrades more rapidly in water than atrazine and a substantial part likely is redistributed to the suspended and bed sediment of streams; reported rapid dissipation of glyphosate (apparent half-lives of as little as 1.5 days) (Goldsborough and Beck, 1989) might contribute to the short duration of concentration peaks.

Although the 2-day data illustrate that a frequent sampling interval might be necessary to identify spikes in surface-water concentrations of glyphosate following application, as previously observed (Goldsborough and Beck, 1989; Annett et al., 2014), these sites might not be representative of the Corn Belt as a whole. The 2-day sites, all in northern Missouri, have 
significantly lower base-flow index and permeability and higher soil $\mathrm{K}$ factor and soil restrictive layer percentage than the other 92 sites (SI Table S-9). The latter three characteristics in particular contribute to rapid runoff and thereby higher, briefer peak contaminant concentrations. Precipitation at 2-day sites during the study was not significantly different from that at weekly sites.

\subsection{Implications for Aquatic Biota and Drinking Water}

Concentrations of glyphosate and atrazine measured in the MSQA streams have differing implications for aquatic life. Glyphosate concentrations were substantially less than thresholds associated with chronic and acute effects (as compiled by Annett et al. [2014]) and typically more than an order of magnitude less than EPA aquatic life benchmarks (U.S. Environmental Protection Agency, 2016). Most adverse effects have been reported at mg/Lorder concentrations, although one study has reported effects on summer algal community structure and eukaryotic diversity at glyphosate concentrations in the range of $10 \mu \mathrm{g} / \mathrm{L}$ (Pesce et al., 2009), the upper end of glyphosate concentrations measured for the MSQA. However, adverse effects for the glyphosate adjuvant POEA (not measured here) likely are of more toxicological consequence than those of glyphosate itself (Folmar et al., 1979; Annett et al., 2014). Atrazine, in contrast, was measured in $20 \%$ of samples at a concentration exceeding the EPA acute aquatic life benchmark of $1.0 \mu \mathrm{g} / \mathrm{L}$ for nonvascular plants but did not approach benchmarks for fish or invertebrates (U.S. Environmental Protection Agency, 2016). Atrazine concentrations measured in some samples, however, were similar to or exceeded those reported by some studies as causing adverse effects to aquatic biota, including amphibians and fish, although the exceedances in the present study typically were for shorter periods than 
those investigated in chronic exposures. For example, Sai et al. (2015) reported that atrazine concentrations of $10 \mu \mathrm{g} / \mathrm{L}$ over 85-day exposures inhibition of metamorphosis and hindlimb extension and changes in testicular structure of the toad Bufo bufo gargarizans Cantor. This concentration was exceeded in about $1 \%$ of weekly and 2-day samples, but was exceeded at no site in more than three successive weekly samples, thus for less than 85 days. Others have reported reduced reproduction in Japanese medaka (Oryzias latipes) (Papoulias et al., 2014) and fathead minnow (Pimephales promelas) (Tillitt et al., 2010) at atrazine concentrations as low as $0.5 \mu \mathrm{g} / \mathrm{L}$ during 14 and 30-day exposures. That concentration was exceeded by the maximum 21-day average concentration of atrazine at 75\% of the MSQA sites.

Although the samples collected for this study are from small streams not typically used as a source of drinking water, those streams feed into downstream source water. Measured concentrations of glyphosate and atrazine therefore can be compared to MCLs-not as regulatory standards but as benchmarks - to place the concentrations in the context of human health. Concentrations of glyphosate measured in the MSQA streams, even at peak concentrations, were a hundred or more times lower than the $\mathrm{MCL}$ of $700 \mu \mathrm{g} / \mathrm{L}$. In contrast, atrazine exceeded its $\mathrm{MCL}$ of $3 \mu \mathrm{g} / \mathrm{L}$ in $8 \%(95$ of 1,997) of weekly samples. Further, weekly sampling underestimated the amount of time that the MCL was exceeded: at the eight 2-day sites, the concentration of atrazine exceeded the MCL in $16 \%$ of 2 -day samples but only $11 \%$ of the weekly samples during the May-August study period. On the other hand, annual mean concentrations-to which MCLs are typically compared-are expected to be lower than the concentrations detected in the MSQA, which were sampled during the high seasonal use period. Further, concentrations downstream likely would decrease as a result of dilution, 
volatilization, and degradation before reaching a drinking-water supply, and concentrations likely would decrease further after water treatment. These results, nevertheless, have implications for surface-water users, and also for users of domestic and public-supply wells, as elevated concentrations of pesticides in surface water in the Corn Belt region have been demonstrated to contaminate nearby groundwater by interception (Warner and Ayotte, 2014).

\section{Conclusions}

Weekly sampling of glyphosate and atrazine during the 2013 growing season in 100 small Midwestern streams revealed different temporal patterns in occurrence of these two commonly used herbicides. The intensity of sampling was made feasible through use of the cost-effective ELISA analytical method to augment the use of the more traditional LC-MS/MS method; the results by ELISA had negligible bias relative to analysis by LC-MS/MS.

Despite a difference in intensity of agricultural use (about 3 times higher for glyphosate compared to atrazine), measured concentrations of glyphosate overall were slightly lower than those of atrazine. This likely is attributable in part to the strong affinity of glyphosate to bind to soils, effectively eliminating subsurface transport, and resulting in little correlation between maximum glyphosate concentration measured at a site and factors likely to affect transport. It might also be attributable to the rapid degradation of glyphosate in water and in soil to its transformation product AMPA. In contrast, maximum atrazine concentration measured at a site was correlated with soil $\mathrm{K}$ factor, organic matter, permeability, soil restrictive layer, and baseflow index. 
Occurrence of glyphosate and atrazine differed by land use. Glyphosate was detected more frequently in urban streams than in agricultural streams, and concentrations measured in urban streams were similar to those measured in streams with a high amount of agricultural land use in the watershed ( $>40 \%$ row crop). In contrast, atrazine was detected more frequently in agricultural streams than in urban streams, and at substantially higher concentrations. Comparison of results for 50 randomly selected sites to those for 38 targeted agriculturalgradient sites indicated that the targeted approach did not produce biased results for these pesticides in agricultural settings, but different detection frequencies for the urban sites indicated that investigation of this high-impact, small footprint land use requires a targeted selection approach.

Measurement of glyphosate and atrazine at a 2-day interval at 8 sites in northern Missouri revealed that temporal patterns in glyphosate and atrazine concentrations were similar at most sites, and that timing of peak concentrations of both herbicides was consistent with a springflush mechanism. Peak concentrations of glyphosate, however, were more transitory than those of atrazine. Early peaks (late May) in concentrations of both herbicides at most of the sites were not captured by the weekly samples collected at the same sites, demonstrating the importance of a frequent sampling interval to identify spikes in surface-water concentrations of these herbicides.

Measured concentrations of glyphosate were substantially less than concentrations associated with acute or chronic effects on aquatic life, and, even at peak concentrations, were 100 or more times lower than the drinking-water MCL of $700 \mu \mathrm{g} / \mathrm{L}$. The maximum of 21-day average concentration of atrazine measured at $75 \%$ of the sites, in contrast, exceeded the 
concentration reported to affect reproduction some fish $(0.5 \mu \mathrm{g} / \mathrm{L})$. Concentrations of atrazine exceeded the MCL of $3 \mu \mathrm{g} / \mathrm{L}$ in $8 \%$ of weekly samples collected in small streams during the study period; annual mean concentrations in any downstream source waters are expected to be substantially lower.

\section{Acknowledgements}

All data can be found in ScienceBase at: dx.doi.org/10.5066/F7SN073J. Support for this study was provided by the USGS National Water Quality Program; data and additional information on the Regional Stream Quality Assessments can be found at: http://txpub.usgs.gov/RSQA/. Any use of trade, product, or firm names is for descriptive purposes only and does not imply endorsement by the U.S. Government.

\section{References}

Agency for Toxic Substances and Disease Registry (2003): Toxicological profile for atrazine. U.S. Department of Health and Human Services, Public Health Service, Atlanta, GA, 2003. http://www.atsdr.cdc.gov/toxprofiles/tp.asp?id=338\&tid=59 (Last accessed October 12, 2016).

Ahmad, R., Rahman, A., 2009. Sorption characteristics of atrazine and imazethapyr in soils of New Zealand: importance of independently determined sorption data. J. Agric. Food Chem. 57, 10866-10875. http://dx.doi.org/ 10.1021/jf901365j.

Annett, R., Habibi, H.R., Hontela, A., 2014. Impact of glyphosate and glyphosate-based herbicides on the freshwater environment. J. Applied Toxicol. 34, 458-479. http://dx.doi.org/10.1002/jat.2997.

Battaglin, W.A., Furlong, E.T., Burkhardt, M.R., Peter, C.J., 2000. Occurrence of sulfonylurea, sulfonamide, imidazolinone, and other herbicides in rivers, reservoirs and ground water in the midwestern United States, 1998. Sci. Total Environ. 248,123-133. http://dx.doi.org/ 10.1016/S0048-9697(99)00536-7. 
Battaglin, W.A., Kolpin, D.W., Scribner, E.A., Kuivila, K.M., Sandstrom, M.W., 2005. Glyphosate, other herbicides, and transformation products in midwestern streams, 2002. JAWRA 41, 323-332. http://dx.doi.org/ 10.1111/j.1752-1688.2005.tb03738.x.

Battaglin, W.A., Meyer, M.T., Kuivila, K.M., Dietze, J.E., 2014. Glyphosate and its degradation product AMPA occur frequently and widely in U.S. soils, surface water, groundwater, and precipitation. JAWRA 50, 275-290. http://dx.doi.org/10.1111/jawr.12159.

Benbrook, C.M., 2016. Trends in glyphosate herbicide use in the United States and globally. Environ. Sci. Eur. 28, 1-15. http://dx.doi.org/ 10.1186/s12302-016-0070-0.

Botta, F., Lavison, G., Couturier, G., Alliot, F., Moreau-Guigon, E., Fauchon, N., et al., 2009. Transfer of glyphosate and its degradate AMPA to surface waters through urban sewerage systems. Chemosphere 77, 133-139. http://dx.doi.org/ 10.1016/j.chemosphere.2009.05.008

Capri, E., Vicari, A. (2010): Environmental fate and behaviour of glyphosate and its main metabolite. European Glyphosate Environmental Information Source. http://www.egeistoolbox.org/documents/10\%20Fate\%20and\%20behaviour\%20v3.2.pdf (Last accessed January 28, 2016).

Childress, C.J.O., Foreman, W.T., Connor, B.F., Maloney, T.J., 1999. New reporting procedures based on long-term method detection levels and some considerations for interpretations of water-quality data provided by the U.S. Geological Survey National Water Quality Laboratory. U.S. Geological Survey Open-File Report 99-193, 19 p. Also available at https://pubs.usgs.gov/of/1999/0193/report.pdf.

Curran, W.S., Lingenfelter, D.D. (2009): Adjuvants for enhancing herbicide performance. Penn State Extension: Agronomy Facts. http://extension.psu.edu/pests/weeds/control/adjuvants-for-enhancing-herbicideperformance (Last accessed February 12, 2016).

Duffner, A., Ingwersen, J., Hugenschmidt, C., Streck, T., 2012. Pesticide transport pathways from a sloped litchi orchard to an adjacent tropical stream as identified by hydrograph separation. J. Environ. Qual. 41, 1315-1323. http://dx.doi.org/ 10.2134/jeq2011.0316

Eligon, J. (2013): After drought, rains plaguing Midwest farms. The New York Times, June 9, 2013. http://www.nytimes.com/2013/06/10/us/after-drought-rains-plaguing-midwestfarms.html?_r=0 (Last accessed February 12, 2016).

European Food Safety Authority, 2015. Conclusion on the peer review of the pesticide risk assessment of the active substance glyphosate. EFSA Journal 13,4302. http://dx.doi.org/ 10.2903/j.efsa.2015.4302.

Farrugia, F.T., Rossmeisl, C.M., Hetrick, J.A., Bisco, M., 2016. Refined ecological risk assessment for atrazine. United States Environmental Protection Agency: EPA-HQ-OPP-2013-02660315.

Folmar, L.C., Sanders, H.O., Julin, A.M., 1979. Toxicity of the herbicide glyphosate and several of its formulations to fish and aquatic invertebrates. Arch. Environ. Contam. Toxicol. 8, 269-278. http://dx.doi.org/ 10.1007/BF01056243.

Gibson, L.R. (2001): Photosynthesis Inhibitors. Agronomy 317--Principles of Weed Science. lowa State University, 2001; http://agron- 
www.agron.iastate.edu/Courses/Agron317/Photosynthesis_Inhibitors.htm (Last accessed January 28, 2016).

Giesy, J.P., Dobson, S., Solomon, K.R., 2000. Ecotoxicological risk assessment for Roundup ${ }^{\circledR}$ herbicide. Rev. Environ. Contam. Toxicol. 167, 35-120. http://dx.doi.org/ 10.1007/9781-4612-1156-3_2.

Gilliom, R.J., Barbash, J.E., Crawford, C.G., Hamilton, P.A., Martin, J.D., Nakagaki, N, et al., 2006. The quality of our Nation's waters-Pesticides in the Nation's streams and ground water, 1992-2001. U.S. Geological Survey Circular 1291, 172 p. Also available at https://pubs.usgs.gov/circ/2005/1291/pdf/circ1291.pdf.

Glozier, N.E., Struger, J., Cessna, A.J., Gledhill, M., Rondeau, M., Ernst, W.R., et al., 2012. Occurrence of glyphosate and acidic herbicides in select urban rivers and streams in Canada, 2007. Environ. Sci. Pollut. Res. 19: 821-834. http://dx.doi.org/ 10.1007/s11356011-0600-7.

Goldsborough, L.G., Beck, A.E., 1989. Rapid dissipation of glyphosate in small forest ponds. Arch. Environ. Contam. Toxicol. 18, 537-44. http://dx.doi.org/ 10.1007/BF01055020.

Grube, A., Donaldson, D., Kiely, T., Wy, L. (2011). Pesticides industry sales and usage 2006 and 2007 market estimates. U.S. Environmental Protection Agency http://www.panna.org/sites/default/files/EPA\%20market_estimates2007.pdf (Last accessed August 7, 2016).

Hanke, I., Wittmer, I., Bischofberger, S., Stamm, C., Singer, H., 2010. Relevance of urban glyphosate use for surface water quality. Chemosphere 81, 422-429. http://dx.doi.org/10.1016/j.chemosphere.2010.06.067.

Helsel, D.R., Hirsch, D.M., 2002. Statistical methods in water resources, Techniques of WaterResources Investigations of the U.S. Geological Survey, book 4, chap. A3, 510 p. Also available at https://pubs.usgs.gov/twri/twri4a3/pdf/twri4a3-new.pdf.

International Agency for Research on Cancer, 1999. Some chemicals that cause tumours of the kidney or urinary bladder in rodents and some other substances. IARC Monographs, vol. 73. Lyon, France.

International Agency for Research on Cancer, 2015. Evaluation of five organophosphate insecticides and herbicides. IARC Monographs, vol. 112. Lyon, France.

Kalkhoff, S.J., Lee, K.E., Porter, S.D., Terrio, P.J., Thurman, E.M., 2003. Herbicides and herbicide degradation products in upper midwest agricultural streams during August base-flow conditions. J.Environ. Quality 32, 1025-1035.

Kolpin, D.W., Thurman, E.M., Lee, E.A., Meyer, M.T., Furlong, E.T., Glassmeyer, S.T., 2006. Urban contributions of glyphosate and its degradate AMPA to streams in the United States. Sci. Total Environ. 354, 191-197. http://dx.doi.org/10.1016/j.scitotenv.2005.01.028.

Mackay, D., Shiu, W.Y., Ma, K.C., 1997. Illustrated handbook of physical-chemical properties and environmental fate for organic chemicals, vol. V. Lewis, NY, 1997, 832 p.

Moran, K.D., TenBrook, P.L., 2011. Sources of pyrethroid insecticides in California's urban watersheds: A conceptual model. In: Pesticide mitigation strategies for surface water quality. American Chemical Society Symposium Series, vol. 1075, chap. 18, 287-308.

Meyer, M.T., Loftin, K.A., Lee, E.A., Hinshaw, G.H., Dietze, J.E., Scribner, E.A., 2009. Determination of glyphosate, its degradation product aminomethylphosphonic acid, and 
glufosinate, in water by isotope dilution and online solid-phase extraction and liquid chromatography/tandem mass spectrometry. U.S. Geological Survey Techniques and Methods, book 5, chap. A10, 32 p. Also available at https://pubs.usgs.gov/tm/tm5a10/pdf/tm5a10.pdf.

Olsen, A.R., Sedransk, J., Edwards, D., Gotway, C.A., Liggett, W., Rathbun, S., et al., 1999. Statistical issues for monitoring ecological and natural resources in the United States. Environ. Monit. Assess. 54, 1-45. http://dx.doi.org/ 10.1023/A:1005823911258.

Papoulias, D.M., Tillitt, D.E., Talykina, M.G., Whyte, J.J., Richter, C.A., 2014. Atrazine reduces reproduction in Japanese medaka (Oryzias latipes). Aquat. Toxicol. 154, 230-239. http://dx.doi.org/10.1016/j.aquatox.2014.05.022.

Pesce, S., Batisson, I., Bardot, C., Fajon, C., Portelli, C., Montuelle, B., et al., 2009. Response of spring and summer riverine microbial communities following glyphosate exposure. Ecotox. Environ. Safe. 72, 1905-1912. http://dx.doi.org/10.1016/j.ecoenv.2009.07.004.

Ramwell, C.T., Kah, M., Johnson, P.D., 2014. Contribution of household herbicide usage to glyphosate and its degradate aminomethylphosphonic acid in surface water drains. Pest. Manag. Sci. 70, 1823-1830. http://dx.doi.org/ 10.1002/ps.3724.

Ryberg, K.R., Vecchia, A.V., Martin, J.D., Gilliom, R.J., 2010. Trends in pesticide concentrations in urban streams in the United States, 1992-2008. U.S. Geological Survey Scientific Investigations Report 2010-5139, 101 p. Also available at http://pubs.usgs.gov/sir/2010/5139/.

Sai, L., Wu, Q., Qu, B., Bo, C., Yu, G., Jia, Q., et al., 2015. Assessing atrazine-induced toxicities in Bufo bufo gargarizans Cantor. B. Environ. Contam. Tox. 94, 152-157. http://dx.doi.org/10.1007/s00128-014-1441-0.

Sandstrom, M.W., Kanagy, L.K., Anderson, C.A., Kanagy, C.J., 2015. Determination of pesticides and pesticide degradates in filtered water by direct aqueous injection liquid chromatography tandem mass spectrometry (DAI LC-MS/MS). U.S. Geological Survey Techniques and Methods, book 5, chap. B11, 54 p. Also available at https://pubs.er.usgs.gov/publication/tm5B11.

Scribner, E.A., Battaglin, W.A., Goolsby, D.A., Thurman, E.M., 2000. Changes in herbicide concentrations in midwestern streams in relation to changes in use, 1989-1998. Sci. Total Environ. 248, 255-263. http://dx.doi.org/10.1016/S0048-9697(99)00547-1.

Scribner, E.A., Thurman, E.M., Goolsby, D.A., Battaglin, W.A., Kolpin, D.W., 2005. Summary of significant results from studies of triazine herbicides and their degradation products in surface water, ground water, and precipitation in the midwestern United States during the 1990s. U.S. Geological Survey Scientific Investigations Report 2005-5094, 27 p. Also available at http://pubs.usgs.gov/sir/2005/5094/pdf/SIR20055094.pdf.

Stoeckel, J.A., Morris, J., Ames, E., Glorver, D.C., Vanni, M.J., Renwisk, W., et al., 2012. Exposure times to the spring atrazine flush along a stream-reservoir system. JAWRA 48, 616-634. http://dx.doi.org/ 10.1111/j.1752-1688.2011.00633.x.

Sullivan, D.J., Vecchia, A.V., Lorenz, D.L., Gilliom, R.J., Martin, J.D., 2009. Trends in pesticide concentrations in corn-belt streams, 1996-2006. U.S. Geological Survey Scientific Investigations Report 2009-5132, 75 p. Also available at http://pubs.usgs.gov/sir/2009/5132/pdf/sir20095132.pdf. 
Thurman, E.M., Goolsby, D.A., Meyer, M.T., Kolpin, D.W., 1991. Herbicides in surface waters of the midwestern United States: the effect of spring flush. Environ. Sci.Technol. 25, 17941796. http://dx.doi.org/ 10.1021/es00022a018.

Thurman, E.M., Goolsby, D.A., Meyer, M.T., Mills, M.S., Pomes, M.L., Kolpin, D.W., 1992. A reconnaissance study of herbicides and their metabolites in surface water of the midwestern United States using immunoassay and gas chromatography/mass spectrometry. Environ. Sci.Technol. 26, 2440-2447. http://dx.doi.org/ 10.1021/es00036a016.

Tillitt, D.E., Papoulias, D.M., Whyte, J.J., Richter, C.A., 2010. Atrazine reduces reproduction in fathead minnow (Pimephales promelas). Aquat. Toxicol. 99, 149-159. http://dx.doi.org/10.1016/j.aquatox.2010.04.011

Tush, D., Loftin, K.A., Meyer, M.T., 2013. Characterization of polyoxyethylene tallow amine surfactants in technical mixtures and glyphosate formulations using ultra-high performance liquid chromatography and triple quadrupole mass spectrometry. J. Chromatogr. A 1319, 80-87.

U.S. Environmental Protection Agency (2008): Risks of glyphosate use to federally threatened California Red-legged Frog https://www3.epa.gov/pesticides/endanger/litstatus/effects/redlegfrog/glyphosate/determination.pdf (Last accessed August 1, 2016).

U.S. Environmental Protection Agency (2016): Aquatic life benchmarks for pesticide registration. https://www.epa.gov/pesticide-science-and-assessing-pesticiderisks/aquatic-life-benchmarks-pesticide-registration (Last accessed August 1, 2016).

U.S. Geological Survey, 2006. Collection of water samples (v. 2.0). U.S. Geological Survey Techniques of Water-Resources Investigations, book 9, chap. A4, 165 p. Also available at http://pubs.water.usgs.gov/twri9A4/.

U.S. Geological Survey (2015): Annual Pesticide Use Maps: 1992-2013. Pesticide National Synthesis Project. https://water.usgs.gov/nawqa/pnsp/usage/maps/ (Last accessed January 21, 2016).

Warner, K.L., Ayotte, J.D., 2014. The quality of our Nation's waters-Water quality in the glacial aquifer system, northern United States, 1993-2009. U.S. Geological Survey Circular 1352, 116 p. Also available at http://dx.doi.org/10.3133/cir1352. 

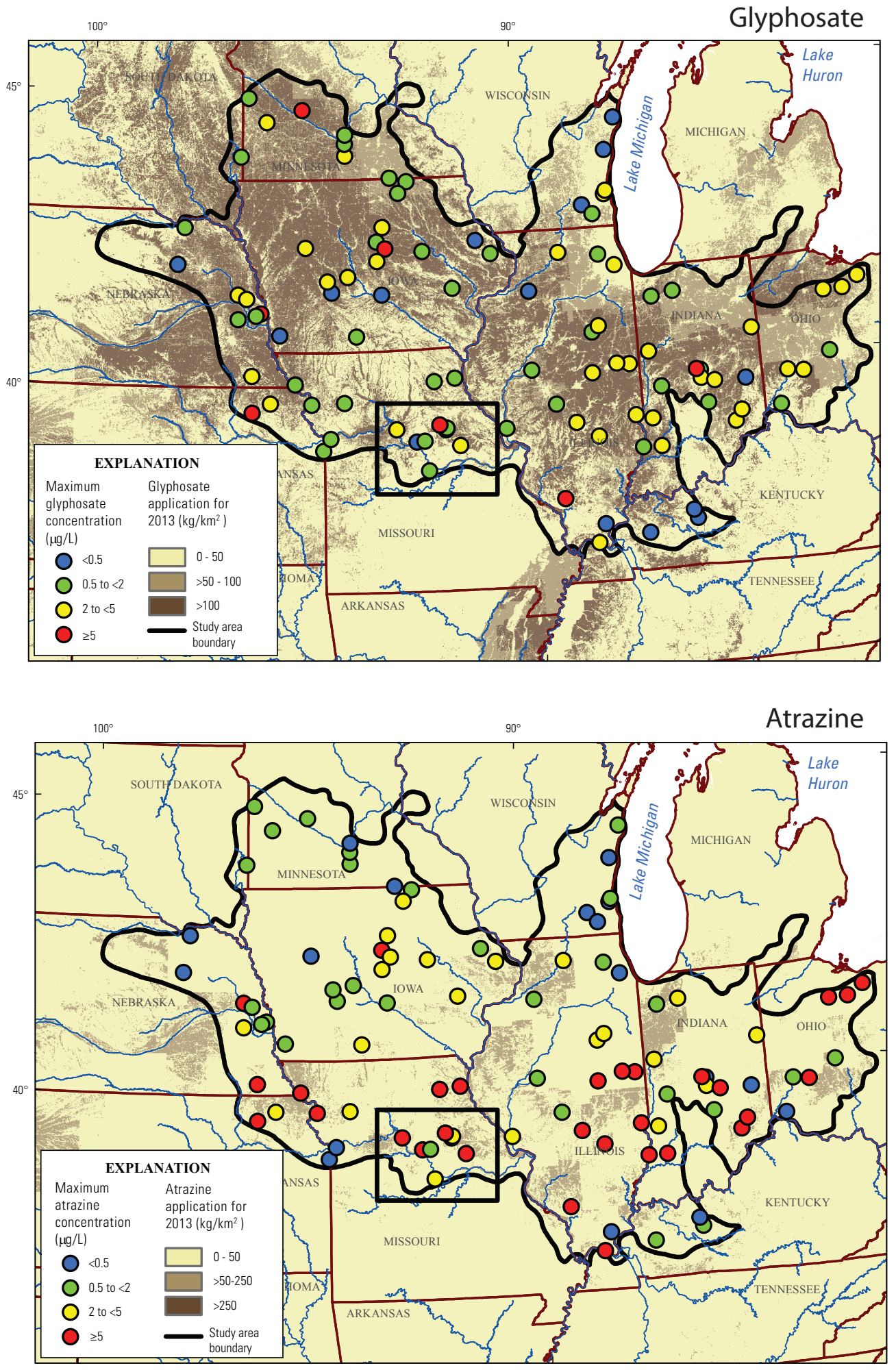

Basemap modified from U.S. Geological Survey 1:2,000,000-scale Digital Data.

Land cover from the National Land Cover Database 2011.

Web Mercator Projection, World Geodetic System of 1984 (WGS 84).

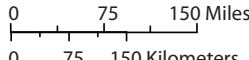

Figure 1. Glyphosate and atrazine agricultural use intensity (2013 data) and maximum aqueous concentrations measured in weekly samples at MSQA stream sites during May-July 2013. Boxes outline 2-day sampling sites in Missouri. Site short names are provided in Supporting Information (SI) table S-2; compound concentrations are provided in SI table S-5. 

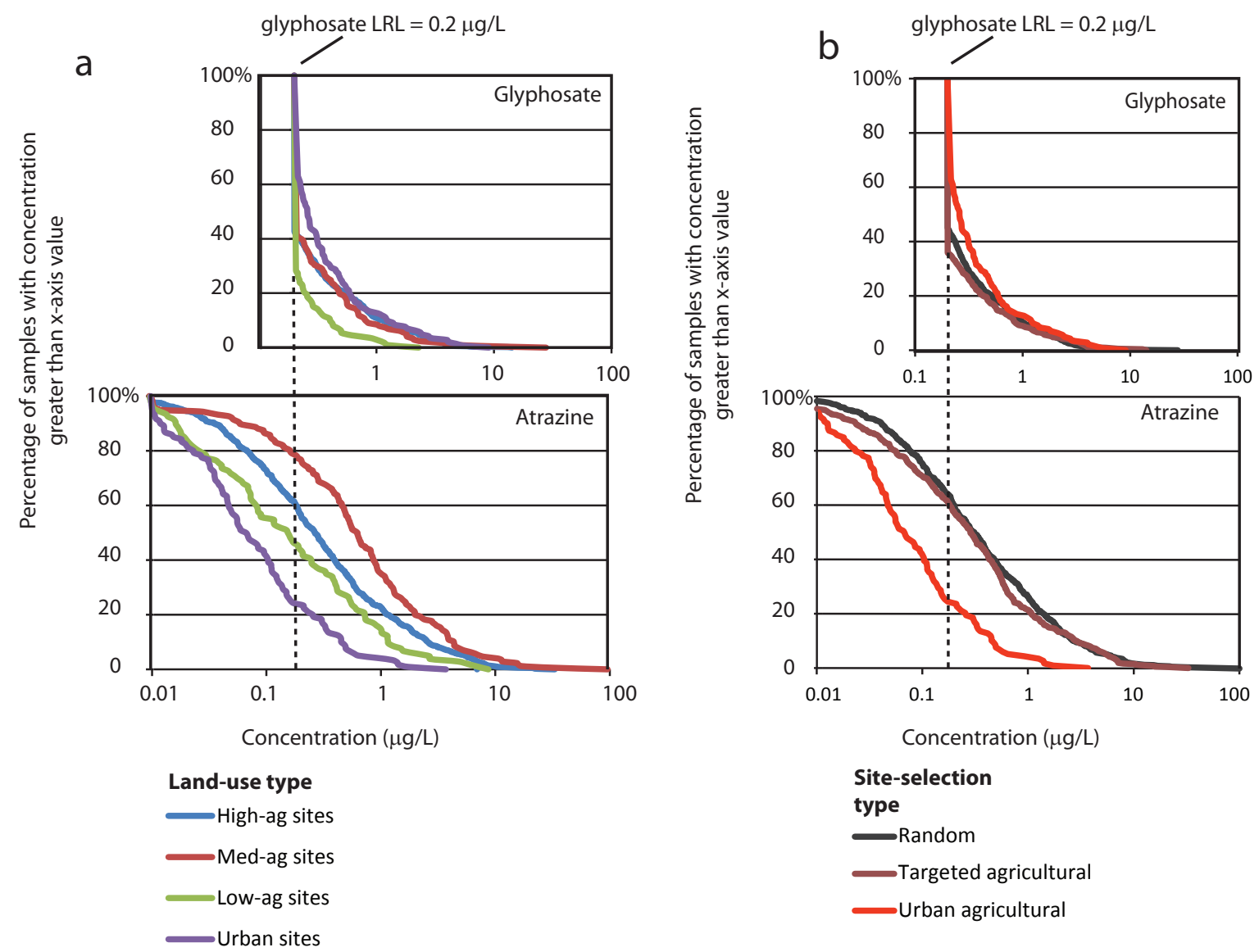

Figure 2. Frequency of detection of glyphosate and atrazine, shown as percentage of all samples with a concentration greater than a given value, (a) by land-use type, and (b) by site-selection type. Agricultural gradient sites: low-ag, $\leq 20 \%$ row crop; med-ag, $>20$ to $\leq$ $40 \%$ row crop; high-ag, $>40 \%$ row crop. LRL, laboratory reporting level. 
Figure 3

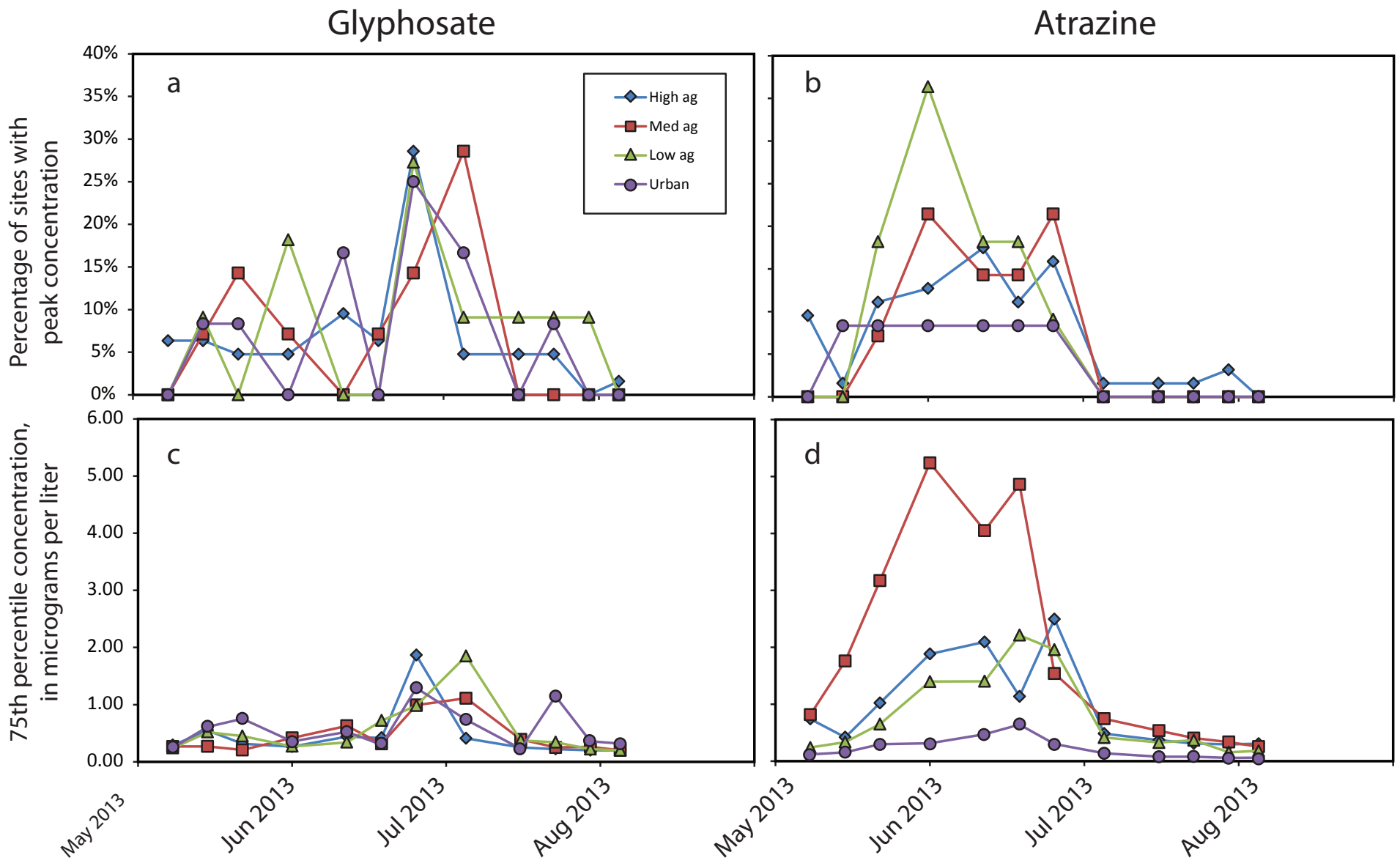

Figure 3. Timing of glyphosate and atrazine peak concentrations, as measured in weekly samples. a and $b$, percentage of sites for a given land use with a peak concentration during a sampling week. $c$ and $d, 75$ th percentile concentration by land use during a sampling week. Agricultural gradient sites: low-ag, $\leq 20 \%$ row crop; med-ag, $>20$ to $\leq 40 \%$ row crop; high-ag, $>40 \%$ row crop. 


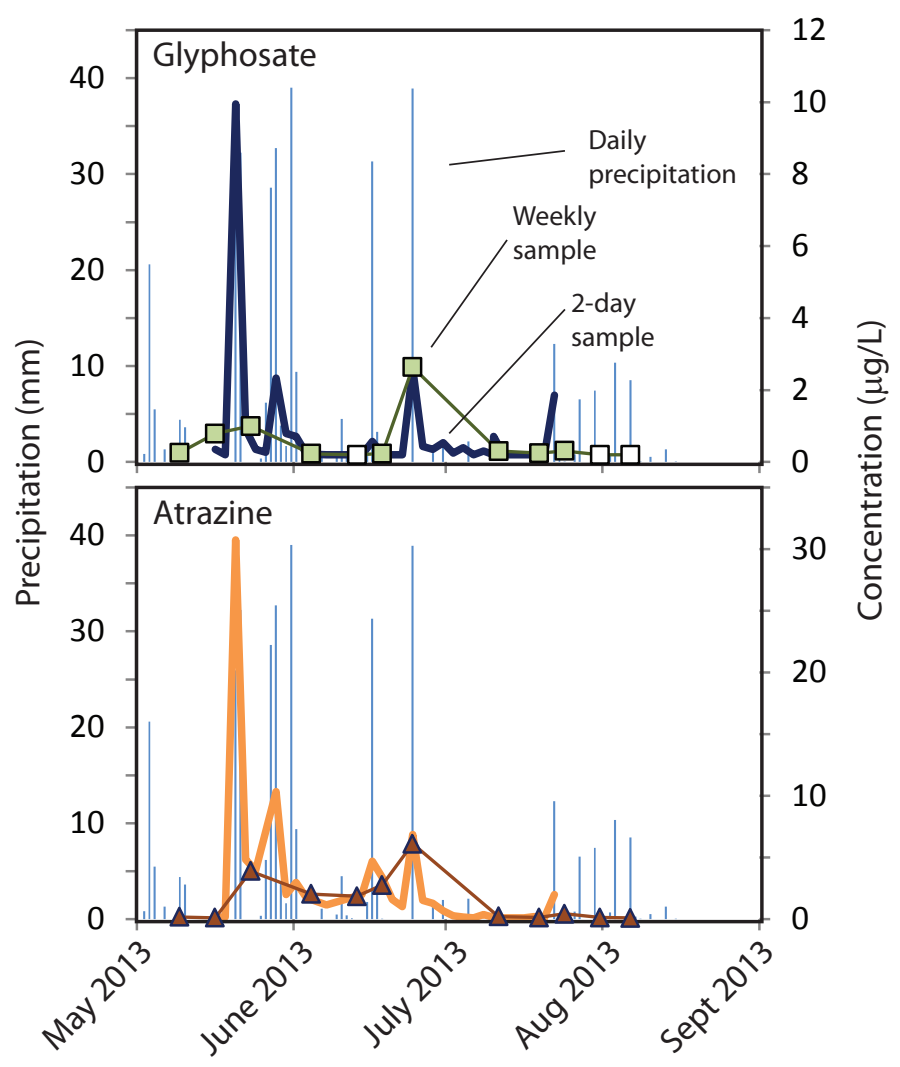

Figure 4. Concentrations of glyphosate and atrazine measured in 2-day (lines) and weekly (symbols) samples at representative site MO_Bear. Open symbols indicate non-detection at the glyphosate laboratory reporting level of $0.2 \mu \mathrm{g} / \mathrm{L}$ for ELISA. Data for all eight 2-day sampling sites are shown in SI Fig. S-4. 
Herbicide use in

study area (kg)

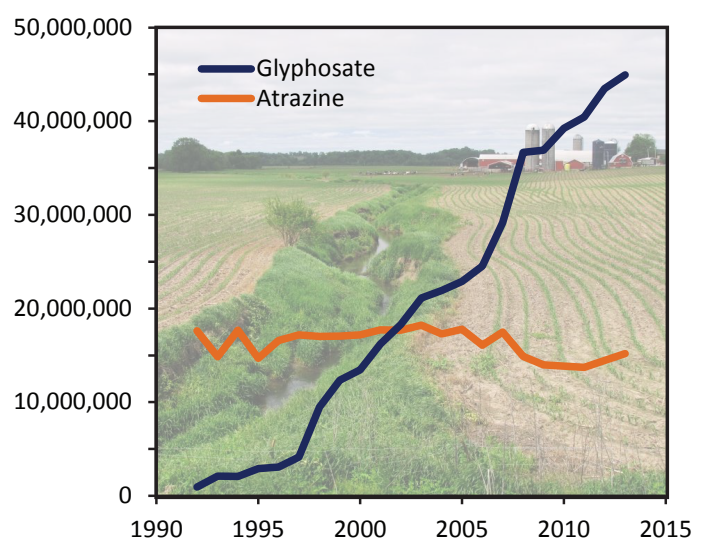

Maximum

concentration at a

site $(\mu \mathrm{g} / \mathrm{L}), 2013$

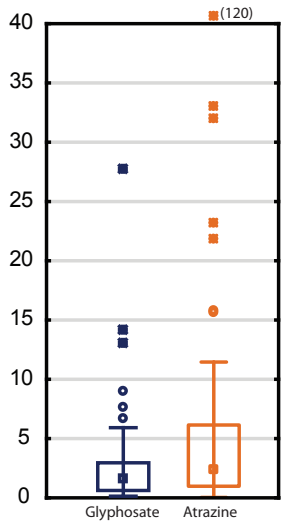

